\title{
Class differences between students' opting for doing an associate degree in community college in Hong Kong: different states of cultural capital and their conversion
}

\section{Introduction}

This article seeks to utilise Bourdieu's conceptual framework published in 1984 to make sense of the educational decision of so-called 'loser' students in contemporary Hong Kong. The last few decades have witnessed a continuous expansion of education in many industrial-capitalist societies; yet, it is well documented that a class gap in educational attainment persists (e.g. Shavit and Blossfeld; Schofer and Meyer; see the collections in Torres and Antikainen). Many sociologists are agreed that such persistent class differential in educational attainment could be understood as a result of class-related distortions in the educational process (Marshall et al.). Indeed, a number of concepts have been proposed and many explanations have been advanced to explain the persistence of such a class gap and illustrate how this takes place (cf. Moore). No one would ever doubt the necessity of sociologists' effort to illustrate how children of an advantaged class (usually labelled as the middle class) are much better able than their disadvantaged class counterparts (usually labelled as the working class) at each branching point - where social selection takes place (usually in the form of public examinations) to decide who could stay on in the education system and who could not after that point - to take advantage of an educational expansion so that the former would eventually attain a higher level of education. More specifically, in the case of Hong Kong, as will be discussed in more detail below, more middle-class students than working-class students pass two public examinations - the two important branching points - and eventually get a bachelor's degree. However, I suggest that attention should also be paid to elucidate how class 
effects operate for students who fail at one of those branching points or both, so-called 'loser' students, so that we could understand why more middle-class students than their working-class counterparts, despite failing at previous stage(s), could still finally get a place in university. The term 'loser' could certainly be criticized for being derogative; but, in using it here, I do not have such intention: for the sake of convenience, I use it simply to refer to students who fail any necessary public examination and thus could not move on to the next stage in an education system.

What I find particularly appealing is Bourdieu's framework and his distinction of three main forms of capital, discussed in his works published in 1984 and 1997: economic capital, cultural capital, and social capital. Bourdieu's capital is different from resources meant by most sociologists (e.g. Treiman and Yip) in two major aspects and is thus, in my view, of greater theoretical relevance in understanding processes of social reproduction in general and the reproduction of educational inequality in particular. First, the term capital implies its capacity to produce profits and to reproduce itself in an identical or expanded form whereas the concept of resources does not have such an implication. Second, where social reproduction is concerned, the concept of cultural capital in particular provides an analytical framework to theorise processes mediating between the family and school in understanding a child's educational career but the concept of cultural resources does not. Certainly we could say that cultural capital and cultural resources are not so different in that they both could be used to refer to one's academic qualification and knowledge about how a system operates. However, what cultural capital implies is more than that; it should be understood together with Bourdieu's concepts of habitus and field, in that it refers to modes of thinking, types of disposition, and sets of meanings derived from an individual's family and thus upbringing (habitus) and how the individual makes use of such cultural capital in a given field (such as in an academic setting) so that s/he could ultimately retain his/her social position.

In the field of an academic setting, the distinction of three states of cultural capital by Bourdieu further makes clear how the concept differs from the concept of cultural resources. Bourdieu argues in his piece in 1997 that cultural capital exists in three states: in the embodied state (in the form of long-lasting dispositions of the mind and body); in the objectified state (in the form of cultural goods such as pictures, books, dictionaries, etc); and in the institutionalised state (a form 
of objectification which must be set apart because it confers entirely original properties on the cultural capital which it is presumed to guarantee) (47). The theoretical importance of this distinction lies in the fact that processes of conversion - concerning the conversion of one state of cultural capital to another and the conversion of one form of capital to another - are taken seriously. For example, the institutionalised state of cultural capital could refer to a relatively advantaged level of qualification in a particular society; through imposing social recognition of such a qualification, it could enable its holders to get a higher paid job. In other words, its holders could derive profits from the institutionalised state of cultural capital by converting it into economic capital. Apart from this conversion, the institutionalised state of cultural capital also makes possible the accumulation of cultural capital in the embodied state. Throughout the process of obtaining a relatively high level of qualification, its holders are going through the process of embodiment or incorporation, in that they would develop particular long-lasting dispositions towards education. Meanwhile, they also get themselves familiarised with the operation of the local education system and also sensitised to any of its further development. Such embodiment would predispose them to solicit relevant information from their social connections for the sake of their children's educational careers. Where collecting relevant information that could enhance the educational career of their children is concerned, the holders' cultural capital either works directly in informing them how to evaluate each option, or it works indirectly in converting itself into their social capital in enabling them to learn about the availability of any (new) options and also to solicit relevant evaluations of each option. Put simply, its holders could derive benefits from the institutionalised state of cultural capital in the field of an academic setting by converting it into its embodied state and, in turn, social capital.

Many sociologists have made use of Bourdieu's conceptual framework in their works (e.g. Nash; Reay; Lareau; Ball), although their Hong Kong counterparts seem lagging behind in this regard. The last few decades have seen scholars researching into educational inequality in Hong Kong make efforts to document its trends or patterns. More specifically, the following finding is established: as is true of many other industrial-capitalist societies, a class gap in educational attainment also exists in Hong Kong (e.g. Pong and Post; Tsang; also see Post for an overview and also a more updated depiction of the current situation in Hong Kong). However, not many of 
them seek to elucidate processes underlying the observed patterns of educational inequality. Yet, even though Bourdieu's conceptual framework has become more widely adopted, not many sociologists apply it to so-called 'loser' students who fail at an important branching point. Perhaps this is partly because such application per se would imply a challenge to Bourdieu's conceptual framework in understanding the reproduction of educational inequality. If Bourdieu's framework is to work, why would we observe middle-class 'loser' students in the first place? It is true that Bourdieu's framework is criticised by some for being too deterministic in explaining social reproduction, placing too much emphasis on structure and leaving not much room for agency (cf. Jenkins). Needless to mention, there is not much room in his framework left for middle-class students to fail. But, we should not forget that what Bourdieu mainly argues is a tendency or disposition. Besides, failing at a branching point does not necessarily mean an end of the educational career of middle-class students but that needs to be fixed, so to speak. In this sense, how middle-class students handle the situation of this kind could illustrate further the operation of Bourdieu's framework. Yet, what Bourdieu has not done is provide us with an illustration of such kind: how do middle-class children, when failing at an important stage, steer themselves back onto the track, so to speak, and how do they differ from their working-class counterparts? With a view to filling this gap, in this article I shall utilise Bourdieu's concept of capital to make sense of the educational decision of so-called 'loser' students who decide to enrol in community college in Hong Kong. Given the newness of community college, as will be indicated shortly, no research about it has been conducted. So, in addition to filling this theoretical gap, this article also seeks to contribute to the local literature on educational inequality by making a start to research into community college education. In what follows, I shall first provide information about the background of this study: a brief description of the education system in contemporary Hong Kong with a highlight of the emergence of community college in 2000 and a discussion of the research design of the study. I shall then move on to discuss how Bourdieu's concepts could enable us to make sense of how fifty-two community college students evaluate different options available and finally come to decide to opt for doing an associate degree at community college. 


\section{Research Background}

This paper reports data of a qualitative study of community college students in contemporary Hong Kong. As in the case of many capitalist-industrial societies, the last few decades have witnessed a coexistence of an educational expansion and the persistence of a class gap in educational attainment in Hong Kong (e.g. Sweeting). At present, a basic education - six-year primary education and three-year junior secondary education - is free, universal, and compulsory; but, the system has remained rather selective, if not elitist, although it has become less so the case over the last six decades. While all people are entitled to a basic education, the number of places in higher education is limited. Therefore, a class gap is observed at the level of higher education (e.g. Post). Since 1995 the existing education policy has set the proportion of the relevant age group getting a place for first-year first-degree at a local university at the level of $16-18 \%$ (the website of Education Bureau, Hong Kong). Getting a place in a local university is basically a two-stage story; students have to survive two important branching points so as to obtain the minimum required results at two public examinations: one is Hong Kong Certificate of Education Examination (HKCEE), which students take at the end of secondary form five; the other is Hong Kong Advanced Level Examination (HKALE), which students take at the end of secondary form seven. Given the existing set quota, obtaining the minimum required results does not guarantee students a place in a local university. In reality, only about $34-36 \%$ of students who take HKCEE could stay on to continue two more years of senior secondary education so as to prepare for HKALE; and then, about $50 \%$ of those who take HKALE would be accepted onto a local university. In evaluating the situation in Hong Kong, especially concerning a drastic rise in unemployment of the age group of 16-25, despite having no intention to expand university education, the Hong Kong government called for providing a greater proportion of students of the relevant age group with a postsecondary education in 1999. In response, the idea of community college was brought into Hong Kong in 2000 (Education Commission Report). Since 2000, the sector of post-secondary education (offering sub-degree programmes such as associate degree, diploma, and higher diploma programmes) has been expanding very quickly. Between 2001 and 2009, the number of institutions offering full-time accredited self-financing post-secondary programmes is nearly double, increasing from 11 to 21 , while the number of associate degree programmes is increased ten-fold 
from 16 to 161 and that of higher diploma programmes nearly six-fold from 22 to 128 (the website of Education Bureau, Hong Kong).

Community college is a new idea to Hong Kong borrowed from the US. In the US, community college, beginning in 1901, is open to all with a low tuition fee; it serves not only to transfer students to a four-year college after two-year studies there but also to offer courses not for transferral such as remedial or vocational courses or courses for personal interests and development (the website of American Association of Community Colleges). In borrowing this idea from the US, the Hong Kong government meant to find an inexpensive way of providing a greater proportion of students of the relevant age group with a post-secondary education: post-secondary degrees awarded by community college were basically designed to be a final degree. However, in practice, community college in Hong Kong differs from its US counterpart in all these aspects. Community college is not open to all; rather, certain entry requirements are commonly adopted. Doing a programme at community college is not cheap at all: its yearly tuition is as much as that for a degree programme, at least $\mathrm{HK} \$ 40,000$, depending on the programme enrolled and also the policy of an individual self-financing institution. And, instead of treated as a final degree, degrees awarded by community college are mainly taken for the purpose of transferral. It is true that so far there are no systematic studies examining the goals of students enrolling in community colleges. But, given a number of demonstrations by community college students demanding for more places in local universities reserved for community college degree holders, and the fact that nearly all community college students are students of the relevant age group, rather than mature students, perhaps it is not an exaggeration to say that most students read a sub-degree, an associate degree more precisely, essentially because they want to get transferred to a local university. In fact, community college has been promoted by those self-financing institutions and seen by most of their students as offering an unconventional route to get into a local university.

In the academic year of 2005-2006, I was teaching the course of 'Introduction to Sociology' for students reading an associate degree in a community college. Given my research interest in educational inequality and the newness of community college, and because of my personal contacts with students there, I started a study on community college students near the end of the first semester in that academic year. At the end of the first semester - in mid-December $2005-1$ 
made announcements in my last lecture and last tutorial in order to recruit students for this study. And then, I did the same in mid-May 2006, the end of the second semester. Out of ethical concerns, I called up students who left their contact information after our professional relationships ended in each semester. Fifty-two students in total were recruited at the two semesters; taped interviews with them were conducted respectively in February and March 2006 and in June 2006. Of the 52 students, 20 are male and 32 female; their age ranges from 20 to 24 , an average being 21. All students failed at an important branching point: they failed one of the two public examinations or both; and, 5 students even re-took HKCEE and 16 HKALE. In the analysis, I use CASMIN class scheme (Erikson and Goldthorpe) to classify students by their parents' occupations: 17 are from the middle class, a relatively advantaged class origin, whereas 35 are from the working class, a relatively disadvantaged class. More specifically, of 17 middle-class students, 8 are from Class II, 6 from Class IIIa, and 3 from Class IVa. And, of 35 working-class students, 14 are from Class IVb, 2 from Class V, 2 from Class VI, and 17 from Class VII. Most of the interviews took about an hour and ten minutes, ranging from forty-five minutes to two hours. All the interviews were then transcribed and translated to English from Cantonese, the major local dialect in Hong Kong. For the present purposes, referring to the part of students' narratives on their considerations in discussing with their parents about each available educational option, I shall use Bourdieu's concept of capital to make sense of their educational choice analysing how they finally came to decide to opt for doing an associate degree at community college.

\section{Educational Options Available in Contemporary Hong Kong Before and After the Emergence of Community College}

To reiterate, the initial idea of setting up community college in Hong Kong was to provide a greater number of students of the relevant age group with a post-secondary education, as opposed to bridging them to a local university. But, the fifty-two community college students of this study, as with many others in Hong Kong, opted for doing an associate degree because they all saw community college as a springboard to a local university. With a view to understanding why students take community college in this way, we should look into what educational options are available before and after the emergence of community college. Before its emergence, students 
had to meet the minimum required results at both HKCEE and HKALE. Failing to do it at HKCEE, students were not qualified to take HKALE; and then, failing to do it at HKALE or not getting high grades at HKALE, students could not get a place in a local university and basically they had four options: to get a paid job, to do a one-or-two-year higher diploma vocational course, to repeat a year of studies and then to re-sit HKALE in the following year, or to study abroad. The first two options usually signified an end of a formal educational career, sooner or later: choosing either of the first two options, students did not aim to receive a university education but wanted to start working; the major difference was whether they wanted to get a paid job immediately (the first option) or to do that a year or two later after doing a vocational course learning a trade or some practical skills (the second option). For those who wanted to stay on in education in the hope that they would eventually get into university, they would choose the third or the last option. Whereas studying abroad was such an expensive option that not every one could afford to take, to repeat a year of studies was a cheap option open to all students: in choosing to repeat secondary form seven at school so as to prepare for HKALE, students just needed to pay some inexpensive school fees; at worst, students could enrol as self-study students preparing for HKALE at home by themselves. However, despite its low exclusivity, many students found this option rather frustrating. What made it so frustrating was subject choice. At HKALE, apart from two compulsory subjects for all students - Chinese language and English language - students had to take four subjects from any of three streams: science stream, arts stream, and commerce stream. In theory, students were free to choose four subjects in each stream; but, in practice, some subjects are usually required in each stream (for example, science students were usually required to take physics and chemistry; arts students were usually required to take either English literature together with world history or Chinese literature together with Chinese history; and, commerce students were mostly required to take book-keeping and accounting). This set up left students with only one or two elective subjects; and unsurprisingly, most of these elective subjects were still academic-oriented subjects. In short, all students did not have much subject choice but had to take academic-oriented subjects in order to prepare for HKALE. So, it was not difficult to understand if students failed to get good grades at HKALE in their first attempt, it was quite unlikely that they would do much better in their second or even third attempt. 
Against this background, the emergence of community college, and thus the availability of associate degree programmes, has changed the situation giving students a lot more subject choices: doing an associate degree at community college, students could choose subjects that are not offered at most secondary schools such as art subjects (e.g. painting and visual arts), business subjects (e.g. business studies and marketing), and social science/humanity subjects (e.g. anthropology, cultural studies, philosophy, political sciences, psychology, and sociology). To reiterate, given the initial goal of setting up community college, an associate degree is essentially treated as a final degree. But, given that community college also serves to bridge students to university and because of this difference in subject choices between community college and traditional grammar school, many students see the option of doing an associate degree programme at community college as an entirely different alternative to getting into university. In particular, for students who do not do well in so-called traditional academic-oriented subjects, they consider that this option would allow them to see if they are simply academically incompetent or they are just not good at traditional academic-oriented subjects. Nevertheless, generally speaking, there are two potential concerns when this option is compared with the option of repeating a year of studies. The first is about the academic standing of an associate degree. The assessments of HKALE are well known and standardised and its academic standards are widely recognised, by local or overseas academic institutions or by local employers; in contrast, given its newness, the assessments and the academic standards of an associate degree remain unknown to everyone and have yet received social recognition. And what concerns community college students most is whether an associate degree could really serve as a springboard, as promised, bridging them to a local university. More specifically, it remains unclear to them how well they should perform academically at community college so that they would get transferred to a local degree programme. Apart from its bridging power, the second potential concern is about the cost of doing an associate degree. As mentioned at the outset, this option is as expensive as doing a local degree programme, meaning that although it is much cheaper than studying abroad, it is still a lot more expensive than the option of repeating a year of studies. Together with the first concern, many students are worried that in choosing to do an associate degree, they may be spending money for nothing if in the end they could not get transferred to a local university. 


\section{Applying Bourdieu's Capital to Contemporary Hong Kong}

To reiterate, the fifty-two community college students of this study choose to try a so-called unconventional route to get into university. While all the students finally decided to take up this unconventional option, class differences were observed in how they reached this educational decision: middle-class and working-class students and their parents have rather different concerns in evaluating other options available vis-a-vis the option of doing an associate degree. With a view to making sense of such class differences, let me first make clear the relevance of Bourdieu's concept of capital.

Perhaps unsurprisingly, the parents of middle-class students in this study differ from their workingclass counterparts in terms of formal qualification. Most of the middle-class parents attained at least a senior secondary level of education in Hong Kong whereas the majority of the workingclass parents did not complete a secondary education; many of them only finished a primary education in China. In following Bourdieu's distinction, the middle-class parents differ from their working-class counterparts in terms of their institutionalised state of cultural capital. What is of significance concerning this class difference is not simply the institutionalised state of cultural capital per se but its conversion to the embodied state of cultural capital and to economic and social capital. Through imposing social recognition for their local and/or relatively high level of formal qualification, the middle-class parents could get a higher-paid professional or managerial or administrative job and thus convert their cultural capital into economic capital and could use it for their children's education. In addition, in obtaining a local and/or relatively high level of qualification, the middle-class parents have gone through the process of embodiment or incorporation and thus nurtured the embodied state of their cultural capital, in that they attach a set of meanings to education, developing particular dispositions towards education that would be beneficial to the development of their children's educational careers in the context of contemporary Hong Kong. Moreover, throughout the process of embodiment, they also get themselves familiarised with the operation of the Hong Kong education system and also sensitised to any of its recent development. This embodiment of the middle-class parents, then, works either directly or indirectly to the favour of their children where collecting relevant information for the children's 
education is concerned. First, such embodiment works indirectly by predisposing the middle-class parents to solicit relevant information, including from their social connections, so that they learn about the establishment of the first community college in the year of 2000 and also the relevant judgements about this new educational option. Second, such embodiment also works directly by enabling them to realise that getting into university through an associate degree has become an option. Whether parents would use economic and/or social capital for their children's education depends very much their dispositions towards education. So, let me first look into class differences in the embodied state of cultural capital. One way of doing it is to examine the views of the parents of fifty-two students on education in general and qualifications awarded by community college in particular.

\subsection{The Embodied State of Cultural Capital: Views on Education and an Associate Degree}

When asked about whether their parents attached importance to their education, nearly all students of this study gave an affirmative answer: their parents considered that it was important for them to get a bachelor's degree, and their parents believed that this qualification would lead them to a good job. In fact, the students themselves also held the same view on education. In short, regardless of whether the intrinsic values of education were taken into account, middle-class or working-class students were aware that they and their parents were taking education instrumentally. I am not sure if we could argue that my finding is culturally specific to the Chinese: the Chinese have been taking education instrumentally, regarding it as a desirable channel for social mobility since the ancient time (cf. Ho). And I am also not sure if this finding could be seen as context specific to the Chinese in Hong Kong: the Chinese in Hong Kong have a reputation of focussing a lot on the utilitarian values of education. But, this finding could perhaps be seen as posing a challenge to a class difference postulated in the existing literature about parents in the West: it is believed that middle-class parents embrace the intrinsic values of education whereas working-class parents take education instrumentally, in that the former attach importance to their children's education because they treasure the value of education to their children's personal development and the latter do that because of their instrumental concern about whether a 
qualification would lead their children to a good job (cf. Kohn). One could certainly argue that such instrumental attitudes of the middle-class students and their parents of this study towards education are peculiar to Hong Kong vis-a-vis their western counterparts. However, what is of interest is that of late, middle-class parents in the West are also reported to be instrumental in taking their children's education (e.g. Ball). So, perhaps, more comparative work is required so as to see whether Kohn's view on class differences in values still makes sense in the West nowadays and also to examine how far we could argue that the Chinese are more likely than their western counterparts to embrace more instrumental values than intrinsic values of education. Regardless, all students of this study reported that their parents were overwhelmed with the instrumental values of education.

Despite taking education instrumentally, the parents of middle-class and working-class students in this study still differ in terms of first, how they see the link between education and their children's future; and second, why they consider it important that their children should have a university degree. The middle-class parents are aware that education is widely taken as a kind of positional good (cf. Hirsch). They understand that what the future labour market requires of their children is not merely a university degree; they want their children to have a university degree not because the intrinsic values of such a qualification will lead their children to a good job, but because they are concerned that their children will become disadvantaged in the future if they do not have a university degree but their competitors do. In other words, the concern of the middle-class parents is not simply about their children's performance, academically or career-wise, in the immediate future, but about whether their children will be able to secure a relatively advantaged level of education so that they could develop a promising career in the long run. Put simply, the middleclass parents see their children's education in a life-time perspective, in that they want their children to have a university degree because they want them to eventually become financially independent: to be able to fend for themselves and, better still, to make a career. In short, the awareness of the middle-class parents concerning the positional nature of education and their disposition or tendency to see their children's education in a life-time perspective are both consistent with what is meant by Bourdieu's embodied state of cultural capital: such embodiment may not be intrinsically good or superior, but it will allow them to give their children context-relevant 
advice on education and thus put their children at an advantage in social competition in contemporary Hong Kong.

This sense of cultural capital is made clearer by comparing them with the parents of working-class students in this study. The working-class parents, by contrast, are rather ignorant about what is required of their children, including what kind of qualification is required in the future labour market. It is true that they know that their children are, or will be, required to have a university degree if they want to secure a good job. But, this does not mean that they recognise the positional nature of education in social competition. Actually they learn about the link between higher qualification and a good job because their children tell them so. Or else, without knowing why, some of the workingclass parents just repeat what they have heard casually from their colleagues that having a university degree is getting more and more important in the labour market. Like their middle-class counterparts, the working-class parents also want their children to have a good qualification and then a good job, and expect them to become able to support themselves. But, what is of utmost concern to them, unlike their middle-class counterparts, is not simply whether their children could become financially independent, but when their children could start working so that their children could make financial contributions to them; in fact, the working-class parents expect their children to support them in their old age. In other words, given their embodied state of cultural capital, or habitus, while knowing the existence of the link between higher qualification and a good job, the working-class parents, unlike the middle-class parents, do not recognise the positional nature of qualification in social competition and are not predisposed to see the relevance of education to their children's future in a life-time perspective. That is, while recognising the instrumental values of education, they do not realise that the significance of a university degree lies in the competitive edge that it can confer relative to other qualifications. Furthermore, constrained by their lack of economic capital, the working-class parents, unlike the middle-class parents, are concerned for when they will be able to lighten their financial burden: in addition to their children's future financial well-being, what is of great concern to them is their very own financial well-being, presently and in the long run. Again, such embodiment is not necessarily bad or inferior, but it will probably lead them to give their children context-irrelevant, if not short-sighted, advice on education and thus may put their children at a disadvantage in social competition in Hong Kong. 
This class difference in embodiment, in turn, leads the middle-class and working-class parents to have rather different views of qualifications awarded by community college. Predictably, in line with how the parents view education in general, they also take such qualifications instrumentally, in that their concern is not about the intrinsic values of an associate degree, but the bridging power of this degree to a local degree programme. But, again, a class difference is observed and Bourdieu's cultural capital could apply to make sense of the difference. As mentioned above, the embodied state of cultural capital of the middle-class parents predisposes them to solicit relevant information about recent changes in education; this conversion of cultural capital into social capital makes them notice the establishment of the first community college and suggest to their children that the children could probably take the option of doing an associate degree at community college as a plausible new alternative. By contrast, lacking such cultural capital, let alone its conversion into social capital, the working-class parents are ignorant of the recent development in the Hong Kong education system: they do not know of the emergence of community college; actually the workingclass students learn about the availability of this option from their teachers and friends. Needless to mention, the working-class parents also do not realise that this option could serve as a new alternative route for getting their children a place in local university; instead, it is the working-class students who tell them so. This class difference in their views on an associate degree, in addition to reflecting their different embodied states of cultural capital, together with the operation of various forms of capital, affects how the middle-class and working-class parents comment on their children's evaluations on each of the available options in general and also whether they see this newly available alternative as a feasible option.

\subsection{Operation of the Three Forms of Capital: Feasibility of the Newly Available Option}

Given their parents' view on education in general and on an associate degree in particular, how did students of this study weigh up each option available and finally come to decide to opt for doing an associate degree at community college? Given the research design, all the students of this study, by definition, did not want to end their educational careers and start working; rather, all of them still wanted to get into university, preferably a local one. All believed that nowadays a bachelor's 
degree was a must for securing a job, not necessarily a well-paid one. Given their belief, they did not see doing a vocational course to get a higher diploma as an option because courses of this kind would provide them with some practical skills but were unlikely to lead them to university, as many students made clear their rationale: 'If I want to get a qualification quick and learn some practical skills, I would have chosen to do a higher diploma in a vocational institution and I wouldn't have come here to do an associate degree.' Whether their belief - that a degree is absolutely necessary for guaranteeing a job - is a myth is beyond the scope of this article; but such a view is consistent with the mainstream idea on the instrumental values of a university education in present-day Hong Kong. So, when asked about their considerations in deciding to opt for doing an associate degree at community college, all the students shared with me how they weighed up each of the following four options: to start working, to study abroad, to repeat a year of studies and to resit HKALE, and to do an associate degree at community college. Perhaps unsurprisingly, a number of class differences are observed.

The first class difference is about how students of this study and their parents take the option of starting to work. Some working-class students mentioned that their parents had asked them to consider this option, but no middle-class students or parents saw it as an option at all. Economic capital is certainly of relevance in making sense of this class difference. As mentioned above, what was of utmost concern to most of the working-class parents was when their children could give them financial support; but their children's future financial contribution was not of concern to the middle-class parents. Given their economic constraint and their need for getting their children's immediate financial contributions, when their children failed HKALE, it seemed absolutely natural that the working-class parents asked the children to consider getting a job and thus starting to work. Yet, the embodied state of cultural capital or habitus and its conversion to social capital also have different parts to play. Given their habitus (seeing the link between their children's education and future financial support to them and thus their own future financial well-being) and their lack of social capital (their ignorance about the emergence of community college and the possibility of using it as an alternative route to get into university), it was simply inconceivable or unthinkable to most working-class parents that they could come up with a new educational option that could allow their children to obtain a university degree. In stark contrast, given their habitus (putting their 
children's education in a life-time perspective) and social capital converted from their embodied state of cultural capital (their awareness of the emergence of community college and the potential bridging power of an associate degree), the middle-class parents were overwhelmed with a concern about how to keep their children in education when the children failed to do that through a traditional route; and it seemed natural to the middle-class parents to take the newly available alternative as a new educational option for their children. In a way, we could also say that a sense of entitlement (to a university degree) was subtly conveyed by how they expressed their concern about keeping their children in education: the issue is not whether their children should get a university degree but how they do it when they fail to do it through the so-called traditional route (cf. Lareau). In brief, it was unthinkable to the middle-class parents that their children should end their educational career at this stage, but the option of starting to work came rather naturally to the working-class parents.

The second class difference is about how students of this study and their parents see the option of studying abroad. Most middle-class students had considered this option and saw it as their plan B, but all working-class students simply did not see it as an option at all. Given the cost of this option, perhaps it was not difficult to understand that their parents' economic constraint was such a great concern to the working-class students that they had never considered it. Nevertheless, class difference in economic capital is not the entire story. Habitus, again, plays a part in enabling us to make sense of why the working-class students, when failing HKALE, and their parents consider studying abroad as an unthinkable option but the middle-class students and their parents see it as a natural alternative. In their immediate social circles, none of the relatives or family members of the working-class students have ever done a degree or studied abroad; the students are usually the first in their families or even their clan groups who could get this far and many see themselves as the only hope of their family to become the first member getting into university. All working-class students did not mention the option of studying abroad until I asked them. This does not mean that the working-class students are unaware of this option; rather, they are just very clear that their parents could not afford for them to take this option. And therefore, even when asked about this option, the working-class students usually replied with a surprising tone as if I should not have asked such question for I should have known their answers, as expressed by Henry: 
Have you ever considered going abroad?

Of course not. Are you kidding me? It is simply impossible. How could my parents afford to support me studying abroad? (Henry, working class)

By contrast, without being probed the middle-class students initiated to discuss this option with me, meaning that this option was already on their agenda. Some of the middle-class students told me that at the moment some of their elder siblings were reading a degree overseas. In a sense, as with their siblings, as well as other relatives, these middle-class students found studying abroad a very natural option, in that they even did not think about the very feasibility of the option: feasibility was not an issue because they know for sure that their parents could afford to send them abroad. What was at issue was when their parents would do that. In truth, some middle-class students did not choose this option for financial reasons but for family reasons. As Brenda explained, her elder sister was presently doing a degree in the US, so her parents wanted her to do a degree in a local university; failing that, her parents still wanted her to be around this year and to study abroad later on.

Actually I could have studied abroad this year. ... But my elder sister is already in the US. And my mother does not want both of us to be away home at the same time; she does not like that empty feeling without her children around. ... So, will see if I can do well at community college this year; if so, my mother prefers that I get transferred into a local university next year. ... Otherwise, I may go abroad later on. (Brenda, middle class)

In brief, some middle-class students took the option of studying abroad as a standby plan B. And this class difference is closely related to the third observed class difference: how students of this study and their parents evaluate the option of repeating a year of studies and retaking HKALE. In evaluating this option vis-a-vis the option of doing an associate degree at community college, the middle-class students basically do not take account of their parents' finances but the working-class students always do. Without economic constraint, the middle-class students are not concerned about family finances in considering the option of repeating; rather, in discussing this option with their parents, they are reminded that they should be concerned only about subject choices: if 
choosing this option, they have to take the same academic subjects that they failed before; and therefore their concern is whether making an effort to repeat the same studies to prepare for HKALE for another year would be really worth the time and effort. Simply put, the fact that repeating a year of studies is a rather inexpensive option is not the point in the middle-class students' discussion with their parents. By contrast, because of their economic constraint, in weighing up this option vis-a-vis other options, in addition to gauging its likelihood of success, the working-class students all have to take account of their parents' finances. Indeed, many of them are questioned by their parents why they do not take this inexpensive option; Harry's case is just an example:

My parents asked me why I didn't repeat a year of studies. And they said that they couldn't understand why I didn't choose a much cheaper option. It would have been much cheaper for them if I had repeated: they only pay a few hundred dollars a month for my school fees. But now they have to pay more than forty thousand a year! (Harry, working class)

Given the newness of the option of doing an associate degree at community college, thus far it has remained unclear whether this qualification will be recognised by local employers and how it will be considered by local universities as well as overseas tertiary institutions. Therefore, regardless of its cost, its newness somehow makes this option a risky one; this concern recurs in every interview and here are two examples:

Sometimes I feel that we are like guinea pigs; we are the very first batches of community college students. The idea and/or set up of community college is so new to Hong Kong; thus far no one is sure of its equivalent qualification - higher than secondary form five or seven or what? Who knows how an employer would rate our qualification? ... And no one is sure whether an associate degree could really bridge us to a local university. ... Somehow I feel I am taking a risky path for myself and I don't know if I have made a right decision. (Ivan, working class)

Well, I think we are like guinea pigs for we are trying an unconventional option. An unconventional option is by definition new, meaning that no one has ever tried it before. ... So, for sure, risk is involved.... But, I think, it is a transitional stage; when it becomes clear to where an associate degree could lead the first batch of community college graduates, people will have a better idea of its bridging power and thus recognise its qualification. (Calvin, middle class) 
In short, a measure of uncertainty is involved in taking the option of doing an associate degree. It is true that all students of this study are anxious about it and therefore find this option rather risky. But, given the cost of this option and the fact that the working-class students have greater economic constraint, they talk in more detail about 'risk' and 'uncertainty' involved in choosing this option than their middle-class counterparts. Although it is basically their parents that pay the tuition fees for all the students, part of what the working-class students meant by 'risk' actually involves whether they would in the end waste their parents' money. Many of them mention that they are under great financial pressure not to fail their parents because the tuition fees really cost their parents a fortune and their parents are genuinely concerned about what they would get in return for such a huge amount of money. According to many working-class students, their parents, given their habitus (their view on education) and their lack of social capital (their ignorance of the recent changes in education), criticised them for taking a gamble on their parents' money as well as the students' very future at community college. In contrast, none of their parents compared the middleclass students' attempt to a gamble; rather, most of the middle-class parents were concerned whether their children were wasting their time in figuring out their career aspirations. As in the case of Larry, he failed HKCEE three times, took a one-year post-secondary programme, and then enrolled in a pre-associate degree programme before getting into an associate degree programme. His parents were not concerned about giving him financial support; rather, they were worried that Larry was just wasting his time - all these programmes would lead him to nowhere if he himself could not figure out what he really wanted to do. Taking together with how the middle-class students take the option of studying abroad, we could say that the middle-class students do not see the option of doing an associate degree as risky as do the working-class students because many middle-class students actually have a safety-net: even if they do not do well at community college and fail to get transferred to a local university, they know that studying abroad is always a viable option standing by. Given the viability of this standby option, it is no wonder that many middle-class students feel much less anxious about the measure of uncertainty involved in doing an associate degree. In stark contrast, to reiterate, studying abroad is simply not an option to the working-class students. Doing an associate degree is basically their last attempt to get into university; failing that, they would very likely end their educational career and thus their dream of 
pursuing a university education. Lacking such a safety-net, the working-class, understandably, express more vividly their risky feeling about studying at community college.

What is also of relevance here is the distinction made by Ball (100) between hot and cold knowledge and its relation to educational choice. Ball's assertion that information is a key dynamic in the operation of education systems is consistent with the recognition of the importance of social capital. However, what Ball wants to argue further is the effect of the source of information on the quality of information (cf. Ball et al.). While formal information provided by the government, schools, colleges, and universities is seen as cold knowledge, informal information that circulates through one's social networks is called hot knowledge. It is true that both hot and cold knowledge informs its receivers of some plain information. But, unlike cold knowledge, in addition to plain information, hot knowledge provides its receivers with evaluations and judgements and thus would probably help them to make better educational choices. As is discussed above, their parents do not simply inform the middle-class students about the availability of this new option but do the analysis with them in order to enable them to make this educational choice; but, in the cases of the working-class students, their parents could neither provide them with relevant and/or updated information, nor could they do the analysis with them; actually it is their teachers and friends who inform the working-class students about the availability of the new option. In this sense, according to Ball, the middle-class students of this study are privileged vis-a-vis the working-class students, because in making this educational choice the working-class students only receive cold knowledge from some formal sources whereas the middle-class students receive hot knowledge directly from their well-informed parents who provide them with quality analysis. While convincing, I am not so sure of the relevance of Balls' argument to this study. It is true that given their ignorance, the parents of the working-class students could not provide their children with relevant advice on which option that the children should take when making another attempt to get into university. It is also true that compared with the working-class parents, the parents of the middle-class students give their children advice of more relevance. Nevertheless, given the newness of the option, it is still too early to comment if opting for doing an associate degree at community college is necessarily a better educational choice. 


\section{Concluding Remarks}

It is well documented that middle-class and working-class parents differ greatly in their ability to enable their children to obtain a relatively high level of education. This observation leads many sociologists to replace meritocracy with 'parentocracy' as ideology to describe the existing education system: when education is taken instrumentally, the educational success of students is essentially determined by the wealth and power of their parents instead of by the ability and effort of the students (cf. Brown). What has not been adequately discussed is how such class effects operate in promoting the educational success of so-called 'loser' students who fail at an important branching point. In this article, I seek to highlight class differences in how students of this type steer themselves back onto track, so to speak, and to discuss how to make sense of the class differences. More specifically, I seek to utilise Bourdieu's concept of capital to analyse class differences underlying how fifty-two students who fail the necessary examination(s) finally come to decide to opt for a newly available educational option in Hong Kong, the option of doing an associate degree at community college.

In sum, given the availability of their capital, of each form, the parents of the middle-class students are informed about the emergence of community college, recognise the potential instrumental values of an associate degree in bridging their children into a degree programme, and provide their children with necessary financial support to go for this new option. In short, they serve as a major source of information for their children: they suggest to their children that the children could consider taking up this option. Besides, they also provide their children with a safety-net in that they are prepared to opt for sending their children to study abroad in case their children in the end fail to get bridged to a local degree programme. By contrast, given a lack of all forms of their capital, the parents of the working-class students do not know of the fact that community college has come into existence, are ignorant about the potential bridging function of an associate degree, and wonder why their children do not opt for an inexpensive alternative in making another attempt to get into university (i.e. repeating a year of studies and retaking HKALE). In brief, they see the newly available option of doing an associate degree at community college as very risky; they comment that by choosing this option their children are taking a gamble on their future. It is them 
whom their children have to convince that this new option is worth taking. Given its newness, it is as yet too early to decide whether taking up this option is a wise educational choice. As all students comment, it is a risky option. However, even if it is not a wise choice, what this article shows is that their parents' use of capital, of various forms, to enable the students to reach this educational decision still puts the middle-class children in an advantaged position vis-a-vis the working-class children: choosing this newly available educational option, the working-class children are making their last attempt to pursue a bachelor's degree and failing this attempt will definitely lead to an end of their educational career and thus their pursuit, but the middle-class children are enjoying an extra opportunity to make another attempt and failing this attempt will just lead them to go for their plan B.

\section{Works Cited}

American Association of Community Colleges. http://www.aacc.nche.edu (28 December 2006)

Ball, Stephen. Class Strategies and the Educational Market: The Middle Classes and Social Advantage. London: RoutledgeFalmer, 2003.

Ball, Stephen, Meg Maguire and Sheila Macrae. Choice, Pathways and Transitions Post-16: New youth, new economies in the global city. London: RoutlegdeFalmer, 2000.

Bourdieu, Pierre. "The Forms of Capital." Education: Culture, Economy, and Society. Eds. A.H. Halsey, Hugh Lauder, Phillip Brown, and Amy Stuart Wells. Oxford: Oxford University Press, 1997. Bourdieu, Pierre. Distinction. Cambridge, Mass.: Harvard University Press, 1984.

Brown, Phillip. "The "Third Wave" Education and the Ideology of Parentocracy." Education:

Culture, Economy, and Society. Eds. A.H. Halsey, Hugh Lauder, Phillip Brown, and Amy Stuart Wells. Oxford: Oxford University Press, 1997.

Education Bureau, Hong Kong. http://www.edb.gov.hk and http://www.edb.gov.hk (28 December 2006 and 20 January 2010)

Education Commission Report. Learning for life, learning through life, reform proposals for the education system in Hong Kong. Hong Kong: Government printer, 2000. 
Erikson, Robert and John Goldthorpe. The Constant Flux: A Study of Class Mobility in Industrial Societies. Oxford: Clarendon Press, 1992.

Hirsch, Fred. Social Limits to Growth. London: Routledge, 1995.

Ho, Ping-ti. The Ladder of Success in Imperial China: Aspects of Social Mobility, 1368-1911. New York: Da Capo Press, 1976.

Jenkins, Richard. "Pierre Bourdieu and the Reproduction of Determinism." Sociology 16 (1982): 270-281.

Kohn, Melvin. Class and Conformity: A Study in Values. Second Edition. Chicago: University of Chicago Press, 1977.

Lareau, Annette. "Invisible Inequality: Social Class and Childrearing in Black Families and White Families." American Sociological Review 67 (2002): 747-776.

Lareau, Annette. Home Advantages: Social Class and Parental Intervention in Elementary Education. Lanham, MD: Rowman and Littlefield, 2000.

Marshall, Gordon, Adam Swift and Stephen Roberts. Against the Odds?: social class and social justice in industrial societies. Oxford: Clarendon Press, 1997.

Mingpao. http://www.mingpaonews.com/20061208/gfd1.htm (8 December 2006)

Moore, Rob. Education and Society: Issues and Explanations in the Sociology of Education. Cambridge: Polity Press, 2004.

Nash, Roy. "Bourdieu on Education and Social and Cultural Reproduction." British Journal of Sociology of Education 11.4 (1990): 431-447.

Pong, Suet-ling, and David Post. "Trends in gender and family effects on school attainment: The case of Hong Kong." British Journal of Sociology 42.2 (1991): 249-271.

Post, David. "Family Resources, Gender, and Immigration: Changing Sources of Hong Kong Educational Inequality, 1971-2001." Social Science Quarterly 85.5 (2004): 1238-1258.

Reay, Diane. "Bourdieu and Cultural Reproduction: Mothers' involvement in their children's primary 
schooling." Bourdieu and Education: Acts of Practical Theory. Ed. Michael Grenfell and David James. London: Taylor and Francis, 1998.

Schofer, Evan and John Meyer. "The Worldwide Expansion of Higher Education in the Twentieth Century." American Sociological Review 70 (2005): 898-920.

Shavit, Yossi, and Hans-Peter Blossfeld. Persistent Inequality: Changing Educational Attainment in Thirteen Countries. Oxford: Westview Press, 1993.

Sweeting, Anthony. Education in Hong Kong, 1941 to 2001: Visions and Revisions. Hong Kong: Hong Kong University Press, 2004.

Torres, Carlos Alberto, and Ari Antikainen. The International Handbook on the Sociology of Education: An International Assessment of New Research and Theory. Lanham: Rowman and Littlefield Publishers, Inc., 2003.

Treiman, Donald, and Kam-Bor Yip. "Educational and Occupational Attainment in 21 Countries." Cross-national Research in Sociology. Ed. Melvin Kohn. Newbury Park: Sage, 1989.

Tsang, Wing-kwong. "Education and Early Socioeconomic Status Attainment in Hong Kong." Occasional Paper No. 23 (1993).

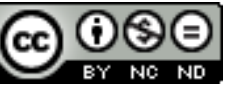

Creative Commons Attribution-NonCommercial-NoDerivatives 4.0 International License 